\title{
Investigation of FecB and POU1F1 Gene Polymorphism in Assam Hill Goat
}

\author{
L. Sarma ${ }^{1 *}$, N. Nahardeka ${ }^{2}$, G. Zaman ${ }^{1}$, A. Aziz ${ }^{1}$, A. Das ${ }^{1}$, F. Akhtar ${ }^{2}$ and S. Upadhyay ${ }^{3}$ \\ ${ }^{1}$ Department of Animal Genetics and Breeding, College of Veterinary Science, Assam \\ Agricultural University, Khanapara, Guwahati- 781 022, Assam, India \\ ${ }^{2}$ Goat Research Station, Assam Agricultural University, Burnihat, Assam, India \\ ${ }^{3}$ AICRP on Post Harvest Engineering and Technology, College of Veterinary Science, \\ Assam Agricultural University, Khanapara, Guwahati- 781 022, Assam, India \\ *Corresponding author
}

\begin{tabular}{|l|}
\hline Ke y w o r d s \\
Assam Hill goat, \\
$\begin{array}{l}\text { FecB, POU1F1, } \\
\text { Polymorphism, } \\
\text { PCR-RFLP }\end{array}$ \\
\hline Article Info \\
\hline $\begin{array}{l}\text { Accepted: } \\
\text { 18 January } 2019 \\
\text { Available Online: } \\
\text { 10 February } 2019\end{array}$ \\
\hline
\end{tabular}

\section{Introduction}

India possesses the second largest goat population in the world with 135.17 million goats $(26.40 \%$ of the country's total livestock) which corresponds to $15.68 \%$ of total goat population in the world (Basic Animal Husbandry and Fisheries Statistics, 2014). The goat population of Assam is 6.169
The present study was carried out for investigation of polymorphism of $F e c B$ and $P O U 1 F 1$ gene in Assam Hill goat. Blood samples pertaining to 80 randomly selected Assam Hill goats having kidding history of single as well as multiple births maintained at three field units viz., Batabari, Nahira and Tetelia under "AICRP on Goat Improvement" were utilized. DNA was extracted using modified phenol chloroform extraction procedure. The quantity and quality of extracted DNA were assessed using spectrophotometry and agarose gel electrophoresis. A $190 \mathrm{bp}$ fragment of $\mathrm{FecB}$ gene and a $450 \mathrm{bp}$ fragment of POU1F1 gene were amplified using Polymerase Chain Reaction (PCR). RFLP analysis of FecB using AvaII enzyme revealed undigested 190 bp product for all the samples. Digestion of POU1F1 with DdeI produced three fragments of $102 \mathrm{bp}, 118 \mathrm{bp}$ and $200 \mathrm{bp}$ in agarose gel electrophoresis for all the samples revealing monomorphism. The POU1F1 PCR-RFLP products were also visualized by loading on $12 \%$ PAGE in $0.5 \mathrm{X}$ TBE buffer which resulted in similar banding patterns. RFLP analysis of POUIF1 gene was also performed by using PstI, resulting in undigested product of $450 \mathrm{bp}$. In sequence analysis, no restriction site was found for $A v a I I$ in $F e c B$ gene and four restriction sites were found for DdeI in POU1F1 gene. Sequence analysis of the samples revealed 99-100\% homology for both the genes among all the samples irrespective of litter size. 
of North-Eastern region of India is nonvegetarian and chevon is the meat of choice. The chevon production in Assam in the year 2012-13 was 11,000 tonnes which was $20 \%$ of the total meat produced in the state (Basic Animal Husbandry and Fisheries Statistics, 2014). The gap between demand and production of meat could be bridged by augmenting the reproductive efficiency and growth performance of the animals. This can conventionally be achieved with the help of established methods of selection and breeding as well as with the modern molecular genetics techniques.

Candidate gene approach provide a good breeding tool that can enhance the frequency of multiple births early in life, which has been proposed as a direct search for Quantitative Trait Loci (QTL) to improve quantitative traits (Tambasco et al., 2003). The information utility from candidate genes in breeding programs has potential to substantially enhance the accuracy of selection and increasing selection differential (Saleha et al., 2012). Detection of genetic markers, along with mutants of the genes associated with economically important traits, could assist the breeders in designing practical animal breeding plans (Davis et al., 2006). Studies have revealed that the ovulation rate and litter size of domesticated sheep could genetically be regulated by a set of different genes, collectively named as $\mathrm{Fec}$ genes. $F e c B$ and Pituitary Transcription Factor $1(P O U 1 F 1)$ are important candidate genes affecting growth and reproduction in small ruminants (Supakorn, 2009).

$\mathrm{FecB}$ gene was first identified in Booroola ewes by Piper and Bindon (1982). It is a single autosomal gene in chromosome number 6 in sheep which is the main reason for higher prolificacy of certain breeds (Montgomery et al., 1994). Original source of Booroola Merino sheep $F e c B$ gene is the
Garole sheep from Sunderban (West Bengal) area of India. $F e c B$ gene has effects on granulosa cell maturation, oocyte development and its function (Abraham and Thomas, 2012). Each mutant FecB gene results in an increase to the ovulation rate of 1.6 times (Montgomery et al., 2001). The $\mathrm{FecB}$ locus contain a conservative substitution mutation Q249R (CAG®CGG), in a highly conserved intracellular kinase signaling domain of the bone morphogenetic protein receptor $-1 \mathrm{~B}(B M P R-1 B)$, has been associated with the hyper-prolific phenotype of Booroola ewes (Mulsant et al., 2001).

POU domain, class 1, Transcription factor 1 (POU1F1) is otherwise known as PIT 1 and GH factor 1 (Supakorn, 2009). Wollard et al., (2000) stated that POU1F1 gene is located on chromosomes 1q21-22 and comprises 6 exons containing the POU domain. POU1F1 gene is a positive regulator of growth hormone, prolactin and thyroid stimulating hormone in mammals (Cohen et al., 1997). The published reviews have reported that genetic polymorphisms of POUIF1 gene were significantly associated with growth, development and lactation in swine, bovine and caprine (Li et al., 1990).

Since $F e c B$ and POUIFI gene have been found to be responsible for prolificacy and, the tendency to twinning and triplet is inherited in both sheep and goats, the present study was carried out to identify the polymorphism of these genes in Assam Hill goats for its possible association with prolificacy and growth performance.

\section{Materials and Methods}

\section{Collection of blood and extraction of DNA}

A total of 80 blood samples from randomly selected Assam Hill goats having kidding history of single as well as multiple births, 
maintained at three field units viz., Batabari, Nahira and Tetelia under 'AICRP on Goat Improvement', Goat Research Station, Burnihat were utilized in the present study. Out of these, 10 samples from animals with history of single birth were taken as control. Five ml of blood was collected aseptically from the jugular vein in a vacutainer tube containing $2.7 \%$ EDTA as anticoagulant. The samples were brought to the laboratory in double walled ice-boxes containing ice packs and stored at $-20^{\circ} \mathrm{C}$ until the genomic DNA was extracted. Genomic DNA was extracted using phenol chloroform extraction procedure (Sambrook and Russell, 2001) with slight modifications by using DNA zol reagent instead of SDS and Proteinase K. The purity of genomic DNA was assessed by UV spectrophotometer (Nanodrop Spectrophotometer, Model: UV/VIS 916) and Optical Density (OD) values were measured at 260 and $280 \mathrm{~nm}$ with TE buffer as blank. The concentration of genomic DNA was estimated spectrophotometrically by taking OD value at $260 \mathrm{~nm}$. Quality of isolated genomic DNA samples was checked by using agarose gel electrophoresis which was visualized under gel documentation system (Kodak 100).

\section{PCR amplification}

The primer pairs F: 5'-CCAGAGGAGAA TAGCAAAGCAAA3' and R: 5'CAAGATG TTTTCATGCCTCAT CAACACGGTC3' (Jamshidi et al., 2013) and, F: 5'-CCATCAT CTCCCTTCTT-3' and R: 5'-AATGTACA ATGTGCCTTCTGAG-3' (Lan et al., 2007) were used to amplify $F e c B$ and POUIF1 gene, respectively. PCR was carried out in 50 $\mu \mathrm{l}$ volume containing $1 \mu \mathrm{l}$ of $10 \mathrm{pmol} / \mu \mathrm{l}$ each primer, $2 \mu \mathrm{l}$ DNA template, $1 \mu \mathrm{l} \mathrm{MgCl}_{2}, 25 \mu \mathrm{l}$ Master Mix and $20 \mu 1$ Nuclease Free Water. Amplification conditions for the two genes were as follows;
The obtained PCR products were separated and confirmed by horizontal submarine agarose gel electrophoresis $(1.5 \%)$ in $1 \mathrm{X}$ TAE buffer at $110 \mathrm{~V}$ using $100 \mathrm{bp}$ DNA ladder.

\section{Restriction Fragment Length Polymorphism (RFLP) analysis}

The PCR products $(20 \mu \mathrm{l})$ of $F e c B$ gene were digested with restriction enzyme AvalI (New England Biolab, UK). For POU1F1 gene, two restriction enzymes DdeI and PstI (New England Biolab, UK) were used. The reaction mixture was vortexed for few seconds for uniform mixing and then incubated at $37^{\circ} \mathrm{C}$ for overnight. The enzyme digested products were loaded @ $10 \mu \mathrm{l}$ on $2.5 \%$ agarose gel. Electrophoresis was carried out at $110 \mathrm{~V}$ for 1 hour and 15 minutes and the bands were visualized and documented using gel documentation system. The bands were analyzed by comparing with 50 bp DNA ladder. In case of POU1F1 gene digested by $D d e I$, the digested products were also visualized by loading on $12 \%$ PAGE in $0.5 \mathrm{X}$ TBE buffer. Electrophoresis was carried out at $100 \mathrm{~V}$ for 3 hours.

\section{Sequence analysis}

The PCR products were sent for sequencing to first base DNA sequencing division, Malaysia. The sequences were analyzed by using Clustal $\mathrm{W}$ method of DNASTAR Software (Lasergene, USA) to generate sequence alignment reports and residue substitution.

\section{Results and Discussion}

A single band on agarose gel confirmed the extraction of DNA. The yield of DNA extracted from $2 \mathrm{ml}$ of whole blood ranged from $106 \mathrm{ng} / \mu \mathrm{l}$ to $247 \mathrm{ng} / \mu \mathrm{l}$ with a mean of $181 \mathrm{ng} / \mu \mathrm{l}$. The OD ratio was in the range of 1.7-1.9 indicating purity of extracted DNA. 
Amplification of $F e c B$ gene resulted in generation of 190 bp DNA fragment (Fig 1) which is consistent with the expected size as reported by Jamshidi et al., (2013) in Sangsari sheep of Iran and Davis et al., (2002) in prolific sheep breeds from eight countries. Amplification of POU1F1 gene resulted in generation of $450 \mathrm{bp}$ product (Fig 2) of the exon 6 and partial intron 5, 3' UTR region which is in agreement with the results reported by Lan et al., (2007) in Inner Mongolia White Cashmere goats.

The RFLP technique was used to identify the variants in $F e c B$ gene based on the variants produced by digestion of $190 \mathrm{bp}$ amplified product with restriction enzyme AvalI. The restriction enzyme was not able to fragment the amplicon of $190 \mathrm{bp}$ as shown in Fig 3. The amplified $190 \mathrm{bp}$ fragment of $\mathrm{FecB}$ gene upon AvaII digestion produced a single band of $190 \mathrm{bp}$. All the animals under the study were found to be monomorphic. The results revealed the absence of mutant type $B$ nucleotide, indicating that the investigated Assam Hill goats were wild homozygous type. Similar results are also reported by Hua et al., (2007) in Boer, Haimen, Boer $\mathrm{x}$ Huanghuai goat, Huanghuai, Nubi and Matou goat, and Jamshidi et al., (2013) in Sangshari sheep. Reports on Jining Grey goats, Boer goats, Wending dairy goats, Liaoning Cashmere goats, Inner Mongolia Cashmere goats, Beijing native goats (He et al., 2006) and Raighar goats (Palai et al., 2013) state the same view of absence of polymorhism in $\mathrm{FecB}$ gene. However, $\mathrm{FecB}$ mutation is present in Garole (Davis et al., 2002) and $\mathrm{Hu}$ (Davis et al., 2006) sheep.

Table.1

\begin{tabular}{|c|c|c|c|c|c|}
\hline Gene & $\begin{array}{c}\text { Initial } \\
\text { denaturation }\end{array}$ & Denaturation & Annealing & Extension & Final extension \\
\hline \multirow[t]{2}{*}{ FecB } & $\begin{array}{c}94^{\circ} \mathrm{C} \text { for } 5 \\
\text { minutes }\end{array}$ & $\begin{array}{c}94^{\circ} \mathrm{C} \text { for } 15 \\
\text { seconds }\end{array}$ & $\begin{array}{c}60^{\circ} \mathrm{C} \text { for } 30 \\
\text { seconds }\end{array}$ & $\begin{array}{c}72^{\circ} \mathrm{C} \text { for } 30 \\
\text { seconds }\end{array}$ & $\begin{array}{c}72^{\circ} \mathrm{C} \text { for } 5 \text { minutes } \\
\text { and } 99^{\circ} \mathrm{C} \text { for } 15 \\
\text { minutes }\end{array}$ \\
\hline & & \multicolumn{3}{|c|}{35 cycles } & \\
\hline \multirow[t]{2}{*}{ POUIF1 } & $\begin{array}{c}94^{\circ} \mathrm{C} \text { for } 5 \\
\text { minutes }\end{array}$ & $\begin{array}{c}94^{\circ} \mathrm{C} \text { for } 45 \\
\text { seconds }\end{array}$ & $\begin{array}{l}54.5^{\circ} \mathrm{C} \text { for } \\
45 \text { seconds }\end{array}$ & $\begin{array}{c}72^{\circ} \mathrm{C} \text { for } 1 \\
\text { minute }\end{array}$ & $\begin{array}{c}72^{\circ} \mathrm{C} \text { for } 10 \\
\text { minutes }\end{array}$ \\
\hline & & \multicolumn{3}{|c|}{35 cycles } & \\
\hline
\end{tabular}

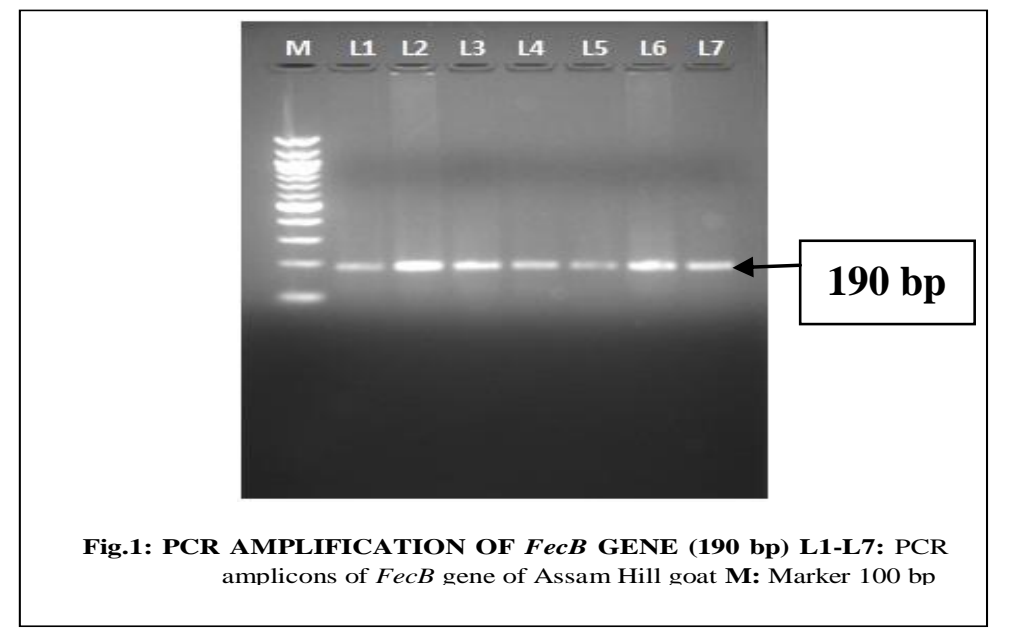




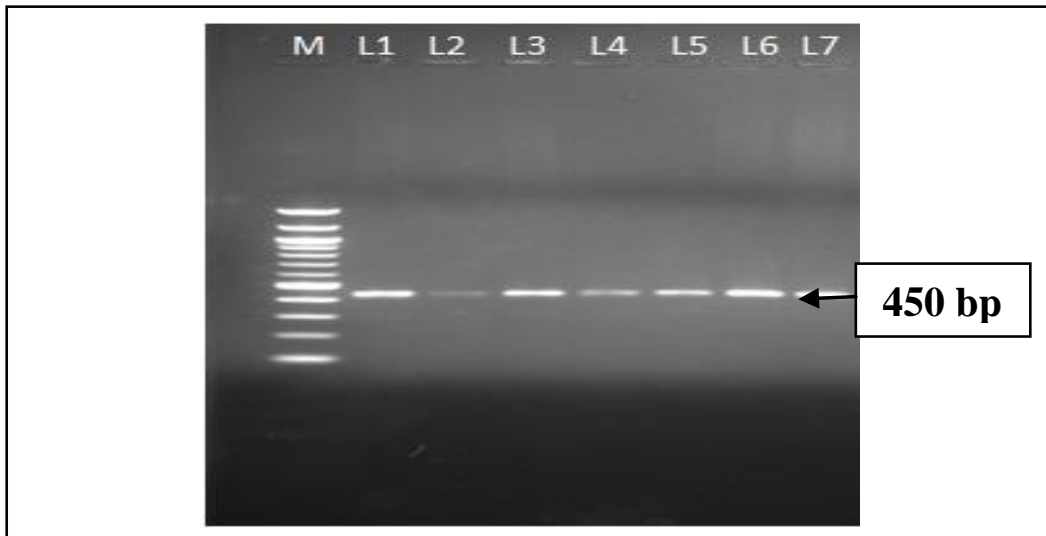

FIG. 2: PCR AMPLIFICATION OF POU1F1 GENE (450 bp) L1-L7: PCR amplicons of $P O U 1 F 1$ gene of Assam Hill goat M: Marker $100 \mathrm{bp}$

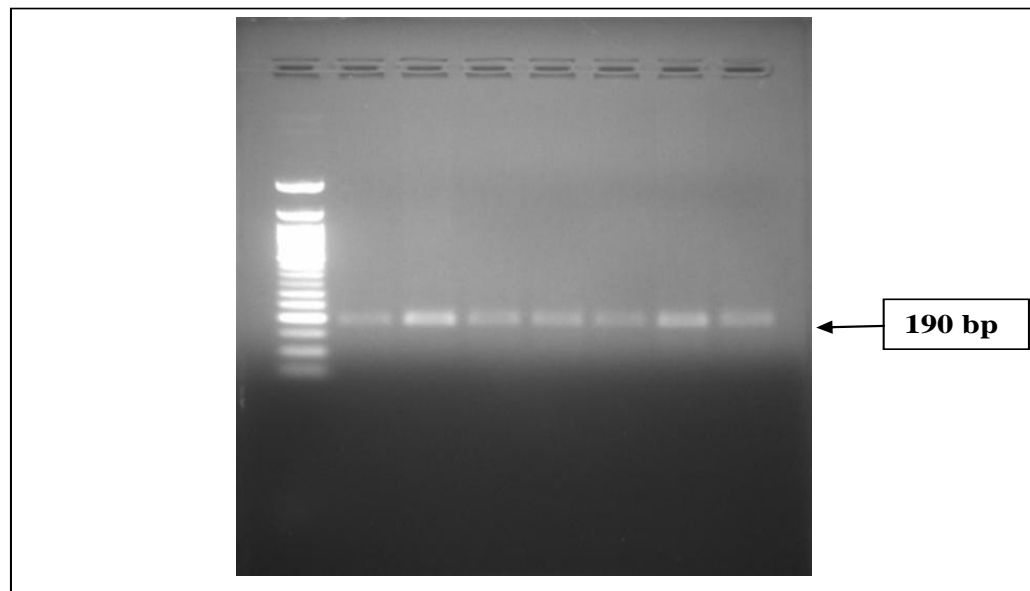

FIG. 3: RFLP OF FecB GENE USING AvaII (190 bp) L1-L7: Undigested products (190 bp), M: Marker $50 \mathrm{bp}$

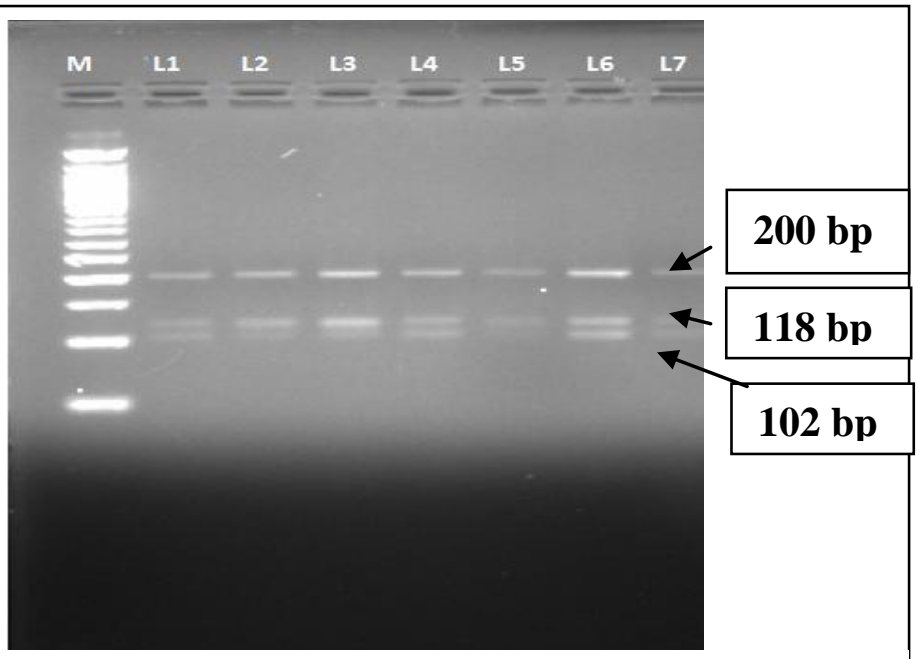

FIG. 4: RFLP OF POU1F1 GENE USING DdeI (102, 118 and 200 L7: Digested products (102, 118 and 200 bp), M: Marker 5 


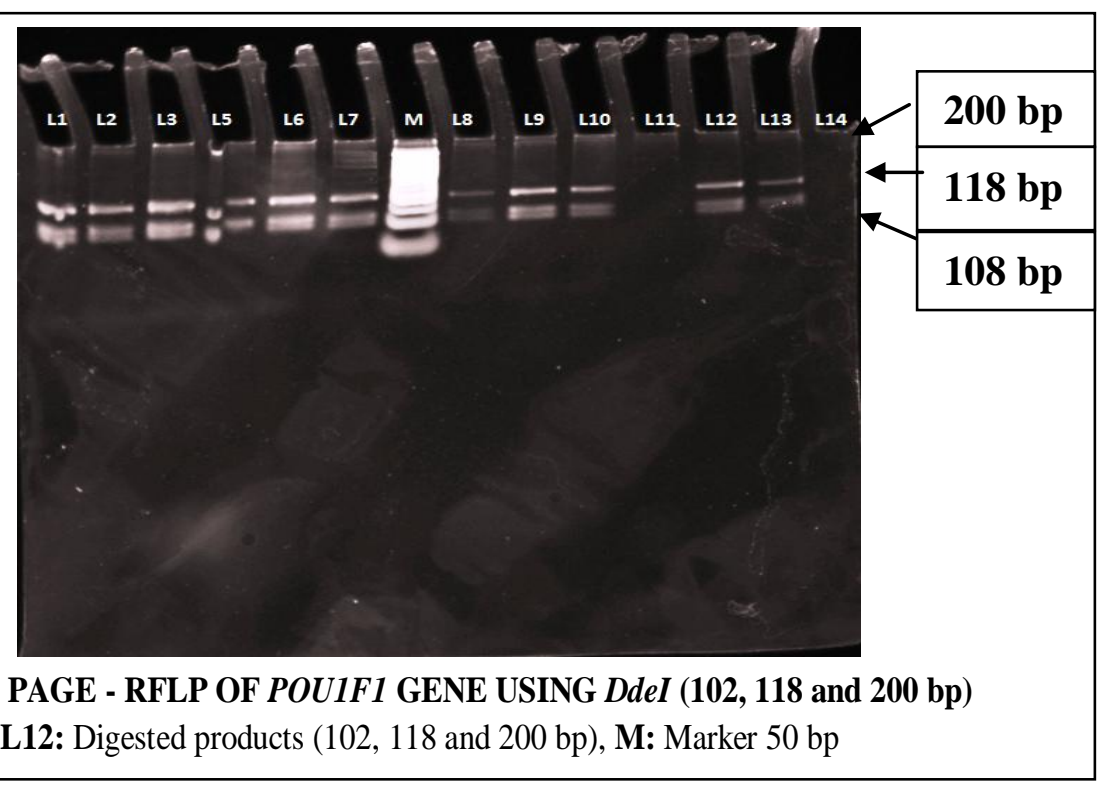

Fig. 5: PAGE - RFLP OF POU1F1 GENE USING DdeI (102, 118 and 200 bp)

L1-L12: Digested products (102, 118 and 200 bp), M: Marker 50 bp

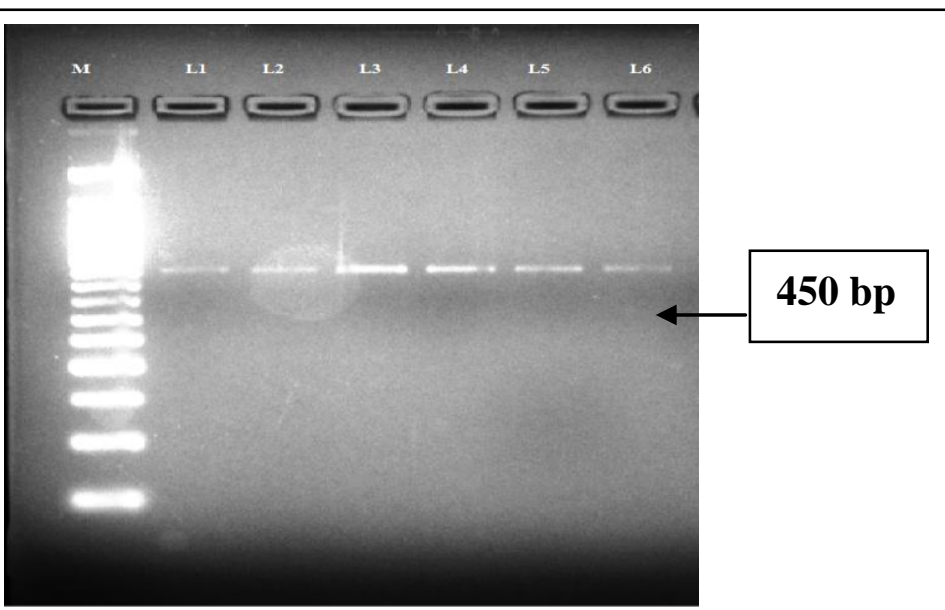

FIG. 6: RFLP OF POU1F1 GENE USING PstI (450 bp) L1-L6: Undigested products (450 bp), M: Marker $50 \mathrm{bp}$

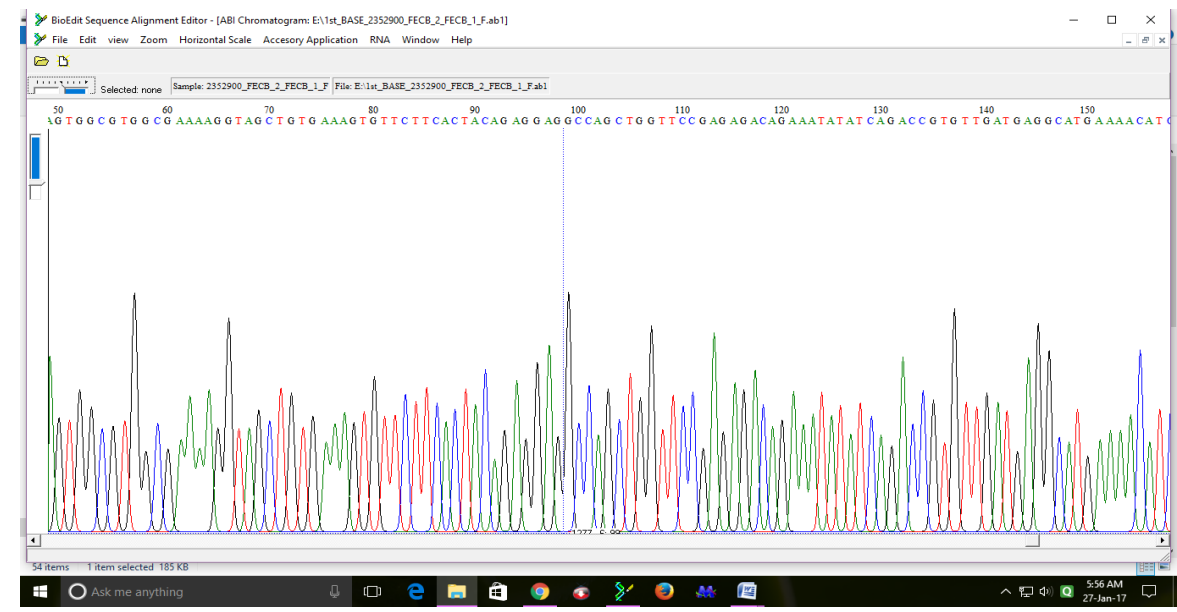

FIG. 7: SCREENSHOT OF THE SEQUENCE OF FecB GENE 


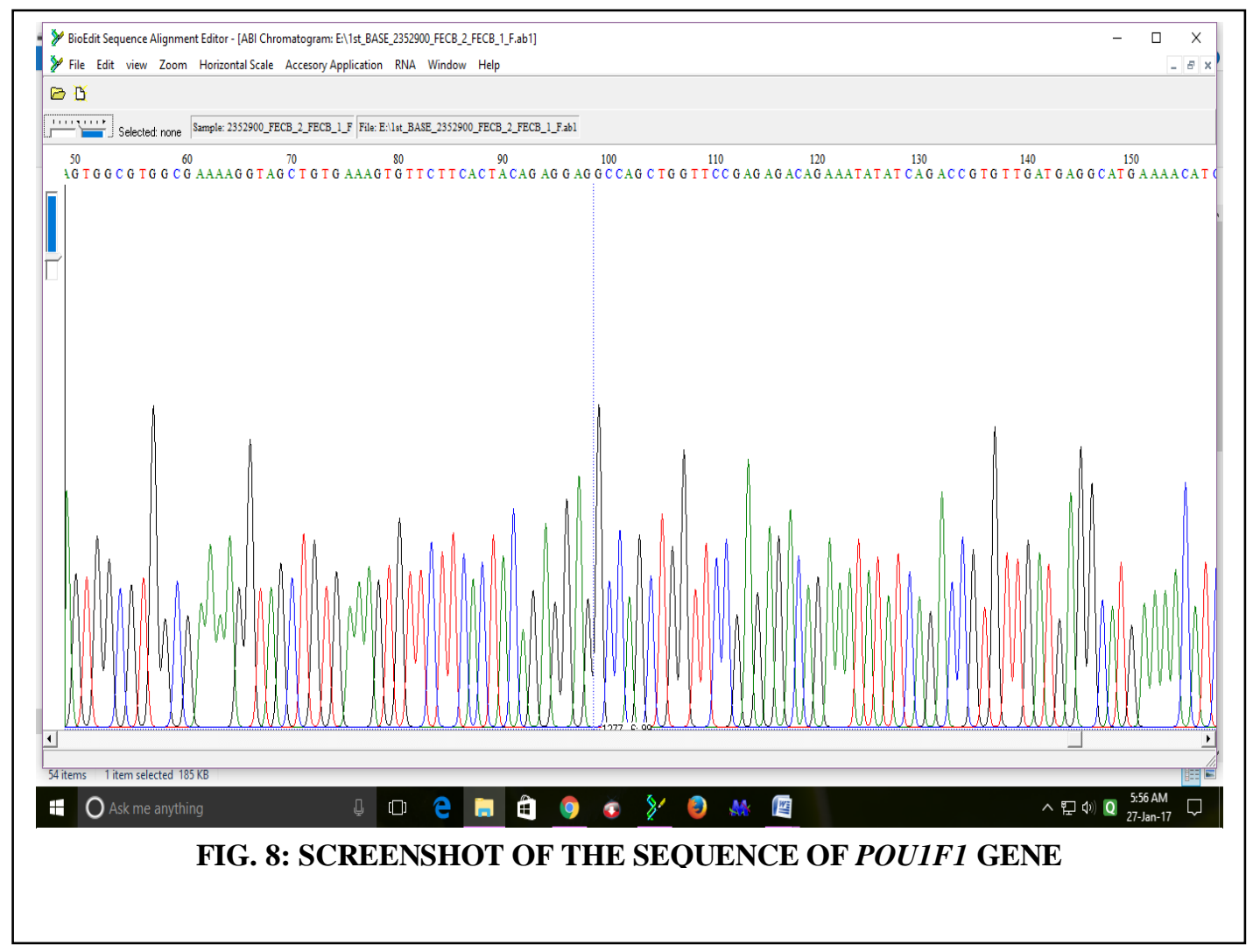

The amplified $450 \mathrm{bp}$ fragment of POU1F1 upon $D d e I$ digestion was expected to produce five fragments of 200,118, 102, 20 and $11 \mathrm{bp}$. However, only three bands of 200, 118 and 102 bp were visible (Fig. 4). The remainder two bands were not visible both in agarose gel electrophoresis as well as in $12.0 \%$ PAGE (Fig. 5) owing to their small sizes. These findings are in accordance with the findings of Li et al., (2016) in 709 indigenous Chinese goats. All the animals under study revealed monomorphic banding patterns. However, the reports of Lan et al., (2007) state polymorphism in exon 6 and its flanking region in Chinese goats. Another restriction enzyme PstI treated PCR products resulted in undigested $450 \mathrm{bp}$ product (Fig 6) which is similar to the findings observed by Sharma et al., (2013) in Barbari goats using PCR-RFLP methods. The Pst1/PCR-RFLP assay of the $450 \mathrm{bp}$ PCR product indicates the presence of single genotype (450 bp) with a genotypic frequency of 1.0 as no polymorphic band pattern was observed. On the contrary, Saleha et al., (2012) in their study on Barki, Zaribi, Ardi and Masri breeds of goat in Egypt and Saudi observe two different banding patterns, undigested product of $450 \mathrm{bp}$ and digested product with two fragments of 370 and $80 \mathrm{bp}$ after digestion by PstI; thus, all samples of goat were typed as allele $\mathrm{T}(450 \mathrm{bp})$ and allele C (370 and $80 \mathrm{bp}$ ) with genotype TT and CC. So, the band pattern obtained after digestion of POU1F1 with Pstl in Assam Hill Goat indicates that all the animals under study revealed TT genotype.

The partial sequences of $F e c B$ and POU1F1 gene were analyzed by BLAST. No restriction site was found for AvaII in $F e c B$ gene and four restriction sites were found for DdeI in $P O U 1 F 1$ gene. All the sequences of the $F e c B$ and POU1F1 genes showed $99-100 \%$ similarity among all the 24 sequenced 
samples irrespective of variation in kid size and growth.

The present findings of monomorphic banding patterns indicate that the amplified fragments of $F e c B$ and $P O U 1 F 1$ gene have no affinity for greater prolificacy in Assam Hill goats. The high prolificacy which was evident from the collected data may be due to some other genes or some other factors which are yet to be explored. This study has highlighted the importance of further investigation for the genes influencing reproductive performance in these goats. Therefore, there is a need to undertake a further research on substantially large number of individuals in Assam Hill goat.

\section{Acknowledgement}

The authors acknowledge the support of AICRP on Goat Improvement, Goat Research Station, Burnihat and Department of Biotechnology, College of Veterinary Science, Khanapara, Guwahati, Assam for conducting the research work.

\section{References}

Abraham, A. and Thomas, N. (2012). Role of fecundity genes in prolificacy of small ruminants. J. Indian Vet. Assoc., 10 (3): $34-38$.

Basic Animal Husbandry and Fisheries Statistics (2014). Department of Animal Husbandry, Dairying and Fisheries, Ministry of Agriculture, Govt. of India.

Cohen, L.E., Wondisford, F.E. and Radovick, S. (1997). Role of Pit-1 in the gene expression of growth hormone, prolactin, and thyrotropin. Endocrinol. Metab. Clin. North Am., 25: 523 540.

Davis, G.H., Galloway, S.M., Ross, I.K., Gregan, S.M., Ward, J., Nimbkar,
B.V., Ghalasi, P.M., Nimbkar, C., Gray, G.D., Subandriyo, Inounu, I., Tiesnamurti, B., Martyniuk, E., Eythorsdottir, E., Mulsant, P., Lecerf, F., Hanrahan, J.P., Bradford, G.E. and Wilson, T. (2002). DNA Tests in prolific sheep from eight countries provide new evidence on origin of the Booroola (Fec B) mutation. Biol. Rerod., 66 (6): 1869 - 1874.

Davis, G.H., Balkrishnan, L., Ross, I.K., Wilson, T., Galloway, S.M., Lumsden, B.M., Hanrahan, J.P., Mullen, M., Mao, X.Z., Wang, G.L., Zhao, Z.S., Zeng, Y.Q., Robinson, J.J., Mavrogenis, A.P., Papachristoforou, C., Peter, C., Baumung, R., Cardyn, Baujenane, I., Cockett, N.E., Eythorsdottir, E., Arranz, J.J. and Notter, D.R. (2006). Investigation of the Booroola (FeC B) and Inverdale (Fec X I) mutation in 21 prolific breeds and strains of sheep samples in 13 countries. Anim. Reprod. Sci., 92: $87-96$.

He, Y.Q., Chu, M.X., Wang, J.Y., Fang, L. and Ye, S.C. (2006). Polymorphism on BMP15 as a candidate gene for prolificacy in six goat breeds. J. Anhui Agric. Univ., 33: $61-64$.

Hua, G.H., Chen, S.L., Ai, J.T. and Yang, L.G. (2007). None of polymorphism of ovine fecundity major genes FecB and FecX was tested in goat. Anim. Reprod. Sci., 108 (3-4): 279 - 86.

Jamshidi, R., Kasirian, M.M. and Rahimi, G.A. (2013). Application of PCRRFLP technique to determine Booroola gene polymorphism in the Sangsari sheep breed of Iran. Turkish J. Vet. Sci., 37: 129 - 133.

Lan, X.Y., Pan, C.Y., Chen, H. and Zhang, C.L. (2007). An AluI PCR-RFLP detecting a silent allele at the goat POU1F1 locus and its association with production traits. Small Rumin. 
Res., 73: 8-12.

Li, M.J., Zhang, C.M., Lan, X.Y., Fang, X.T., Lei C.Z. and Chen H. (2016). Analysis of POU1F1 gene DdeI polymorphism in Chinese goats. Gen. \& Mol. Res., 15 (1): gmr. 15017747.

Li, S., Crenshaw, E.B. III., Rawson, E.J., Simmons, D.M., Swanson, L.W. and Rosenfeld, M.G. (1990). Dwarf locus mutants lacking three pituitary cell types result from mutations in the POU-domain gene Pit- 1. Nature, 347: 528-533.

Montgomery, G.W., Galloway, S.M., Davis, G.H. and McNatty, K.P. (2001). Genes controlling ovulation rate in sheep. Reproduction, 121: 843 - 852 .

Montgomery, G.W., Lord, E.A., Penty, J.M., Dodds, K.G., Broad, T.E., Cambridge, L., Sunden, S.L., Stone, R.T. and Crawford, A.M. (1994). The Booroola fecundity (FecB) maps to sheep chromosome 6. Genomics, 22: $148-$ 153.

Mulsant, P., Lecerf, F., Fabre, S., Schibler, L., Monget, P., Lanneluc, I., Pisselet, C., Riquet, J., Monniaux, D., Callebaut, I., Cribiu, E., Thimonier, J., teyssier, J., Bodin, L., Cognie, Y. and Elsen, J.M. (2001). Mutation in bone morphogenetic protein receptor $-1 \mathrm{~B}$ is associated with increased ovulation rate in Booroola Merino ewes. Proc. Natl. Acad. Sci., USA. 98: 5104 5109.

Palai, T.K., Bisoi, P.C., Maity, A., Behera, P.C., Sahoo, G., Polley, S. and De, S. (2013). Prolificacy in Raighar goats is independent of FecB gene. Vetworld,
3: 479-481.

Piper, L.R. and Bindon, B.M. (1982). The Boorola Merino and the performance of medium non-Peppin crosses at Armidale. In The Booroola Merino, pp. 9-20. Melbourne: Ed. CSIRO.

Saleha, Y.M.A., Mahrous, K.F., Salem, L.M. and Ahmed, E.S. (2012). Genetic polymorphism of five genes associated with growth traits in goat. African J. Biotech., 11 (82): 14738 14748.

Sambrook, J. and Russell, D.W. (2001). Molecular Cloning: A Laboratory Manual III. Cold Spring Laboratory Press, NY, Cold Spring Harbour.

Sharma, S., Tiwari, M., Sharma, D., Singh, S.P., Sharma, A. and Pandey, V. (2013). The study of PIT1/POU1F1 gene polymorphism in Indian Barbari goats using PCR-RFLP methods. Indian Vet. J., 90 (11): 15 - 16.

Supakorn, C. (2009). The Important Candidate Genes in Goats. Walailak $J$. Sci. Tech., 6:17-36.

Tambasco, D.D., Paz, C.C.P., TambascoStudart, M., Pereira, A.P., Alencar, M.M., Freitas, A.R., Coutinho, L.L., Packer, I.U. and Regitano, L.C.A. (2003). Candidate genes for growth traits in beef cattle cross Bos taurus $\times$ Bos indicus. J. Anim. Breed. Genet., 120: $51-56$.

Woollard, J., Tuggle, C.K. and Ponce de Leon, F.A. (2000). Rapid communication: localization of POU1F1 to bovine, ovine, and caprine 1q21-22. J. Anim. Sci., 78: 242-243.

\section{How to cite this article:}

Sarma, L., N. Nahardeka, G. Zaman, A. Aziz, A. Das, F. Akhtar and Upadhyay, S. 2019. Investigation of FecB and POU1F1 Gene Polymorphism in Assam Hill Goat. Int.J.Curr.Microbiol.App.Sci. 8(02): 2366-2374. doi: https://doi.org/10.20546/ijcmas.2019.802.275 